Berkala Ilmu Perpustakaan dan Informasi, Vol. 17, No. 2, Desember 2021, Hal. 195-206 https://doi.org/10.22146/bip.v17i1.1103

ISSN 1693-7740 (Print), ISSN 2477-0361 (Online)

Tersedia online di https://journal.ugm.ac.id/v3/BIP

\title{
Hubungan kualitas informasi repositori ilmiah nasional dengan tingkat kepuasan di Lembaga Ilmu Pengetahuan Indonesia Bandung
}

\author{
Alwi Alfiana ${ }^{1}$, Edwin Rizal ${ }^{2}$, Rully Khairul Anwar ${ }^{3}$ \\ ${ }^{1,2,3}$ Program Studi Ilmu Informasi dan Perpustakaan, Fakultas Ilmu Komunikasi Universitas Padjadjaran \\ ${ }^{1,2,3}$ Jalan Raya Bandung Sumedang, Jawa Barat, 45363 \\ e-mail: alwialfiana7@gmail.com
}

\section{Naskah diterima: 1 Juli 2021, direvisi: 13 Agustus 2021, disetujui: 7 Oktober 2021}

\begin{abstract}
ABSTRAK
Pendahuluan. Perkembangan dalam bidang teknologi informasi semakin pesat dari waktu ke waktu. Repositori berbasis digital merupakan bentuk dari adanya pemanfaatan teknologi informasi. Penelitian ini bertujuan untuk mengetahui sejauh mana sebuah sumber informasi seperti repositori memiliki kualitas sistem yang mampu menghasilkan sebuah informasi yang berkualitas sehingga memberikan kepuasan terhadap penggunanya.

Metode penelitian. Penelitian ini menggunakan metode studi korelasional dengan pendekatan kuantitatif. Sehingga populasi dari penelitian ini adalah para pengguna dari Repositori Ilmiah Nasional yaitu peneliti LIPI kawasan Bandung.

Data analisis. Penelitian ini menggunakan analisis statistika deskriptif dan analisis statistika inferensial dengan menggunakan uji Rank Spearman melalui bantuan aplikasi SPSS.

Hasil dan Pembahasan. Hasil dari penelitian memberikan sebuah gambaran bahwa variabel kualitas informasi memiliki hubungan yang signifikan dengan tingkat kepuasan pengguna dari Repositori Ilmiah Nasional.

Kesimpulan dan Saran. Penelitian ini menunjukkan bahwa sistem dari RIN mampu untuk memberikan kualitas terhadap informasi yang diberikan, sehingga memberikan dampak terhadap tingkat kepuasan dari para pengguna RIN itu sendiri. Hal ini disebabkan karena RIN mampu untuk memenuhi indikasi bahwa sebuah informasi disebut berkualitas dengan meliputi time dimension, content dimension dan format dimension.
\end{abstract}

Kata kunci: kualitas informasi; kepuasan; repositori; Repositori Ilmiah Nasional

\section{ABSTRACT}

Introduction. The development in the field of information technology is growing rapidly from time to time. Digital-based repositories are a form of the use of information technology. Therefore, this study focuses on knowing the extent to which an information source such as a repository has a quality system that is able to produce quality information so as to provide satisfaction to its users.

Research methods. This study used a correlational study method with a quantitative approach. The population were users of the National Scientific Repository, namely LIPI researchers in the Bandung area.

Data Analysis. This study used a descriptive and inferential statistical analysis using the Spearman Rank test with SPSS application.

Analysis Data. The results showed that the information quality variable has a significant relationship with the level of user satisfaction of the National Scientific Repository.

Results and Discussion. The results of the study provide an illustration that the information quality variable has a significant relationship with the level of user satisfaction of the National Scientific Repository.

Conclusions and Suggestions. This study shows that the system of National Scientific Repository is able to provide quality to the information provided, that having an impact on the level of satisfaction of the users of National Scientific Repository itself. Information quality should consider several dimensions such as time, content and format.

Keywords: information quality; satisfaction; repository; National Scientific Repository 


\section{A. PENDAHULUAN}

Saat ini perkembangan dalam bidang teknologi menjadi semakin pesat. Kemajuan teknologi dan informasi dapat menjadi kekuatan atau pendorong bagi berbagai pihak untuk terus mengikuti perkembangan zaman, sehingga mampu memenuhi kebutuhan informasi. Hal ini dikarenakan keadaan dunia saat ini yang semakin mengglobal dan secara tidak langsung telah memaksa setiap individu ataupun lembaga untuk dapat mempertajam pengamatannya terhadap informasi-informasi yang didapatkan. Oleh karena itu setiap individu ataupun lembaga dituntut untuk dapat meningkatkan kualitas agar dapat mengikuti perkembangan zaman. Tentu hal ini merupakan salah satu motivasi yang mendorong lembaga-lembaga ataupun oleh pihak-pihak yang memiliki kesadaran betapa pentingnya sebuah informasi atau data yang ada. Berkembangnya teknologi informasi dalam bentuk digital ini merupakan hal yang cukup berpengaruh dalam kehidupan manusia. Pencari informasi lebih menyukai mencari sumbersumber informasi melalui internet karena dianggap lebih memberikan kecepatan dan ketepatan dalam penelusuran informasi yang diinginkan. Menghadapi hal ini, maka beberapa pihak terkait memulai inovasi untuk membuat sebuah media sumber informasi yang dapat dipercaya dengan kemudahan akses sesuai keinginan masyarakat.

Repositori adalah satu set layanan yang diberikan oleh universitas kepada anggota masyarakat untuk melakukan pengelolaan dan penyebaran materi dalam bentuk digital yang dibuat oleh lembaga dan anggota masyarakat (Suwanto, 2017). Salah satu pemanfaatan dari perkembangan di bidang teknologi informasi adalah dengan adanya sebuah repositori digital. Repositori dalam bentuk digital merupakan sebuah tempat penyimpanan data yang dipelihara sebaik mungkin untuk dapat ditemukan kembali pada saat dibutuhkan. Dilihat dari penjelasan tersebut, maka dapat dikatakan bahwa repositori merupakan sebuah media yang memiliki kegunaan untuk memudahkan siapa saja dalam mencari informasi yang dibutuhkan. Perkembangan ini juga disadari oleh pihak-pihak lain yang memiliki kesadaran akan perkembangan zaman saat ini. Oleh karenanya, ada persaingan dalam hal memberikan informasi kepada para pencari informasi dalam menggunakan sumber informasi yang ada. Berbagai sumber informasi digital berusaha untuk memenuhi kebutuhan informasi para penggunanya dengan memberikan informasi yang berkualitas. Hal ini karena para pengguna kesulitan dalam memilih layanan sumber informasi mana yang mereka inginkan.

Salah satu lembaga terpercaya dalam memahami betapa pentingnya kualitas informasi adalah Lembaga Ilmu Pengetahuan Indonesia atau lebih dikenal dengan LIPI. LIPI menyadari betapa pentingnya memberikan informasi yang berkualitas. Hal ini dibuktikan dengan adanya sebuah terobosan di bidang teknologi informasi yaitu menciptakan sebuah repositori berbasis digital yang dikenal dengan nama Repositori Ilmiah Nasional atau disingkat RIN. Sebagai salah satu sumber informasi berbasis digital yang mengumpulkan berbagai hasil penelitian, RIN sudah seharusnya memberikan informasi yang berkualitas bagi para penggunanya. Kehadiran RIN diharapkan dapat mendukung para penggunanya dalam menciptakan karya ilmiah yang baik dan memudahkan dalam mencari informasi yang relevan.

Sumber informasi yang memberikan informasi berkualitas dapat menumbuhkan kepercayaan kepada penggunanya. Harapan dan kebutuhan para pengguna yang terpenuhi akan menimbulkan sikap kepuasan atas penggunaan sumber informasi digital yang dipilih. Kepuasan dalam penggunaan sumber informasi akan timbul setelah pengguna menggunakan suatu sumber informasi berbasis digital. Kepuasan juga dapat dijadikan sebagai penilaian mengenai ciri dari sebuah produk atau jasa. RIN sebagai sebuah sumber informasi digital dalam bentuk repositori harus memberikan informasi yang berkualitas, sehingga pengguna akan percaya dan memberikan rasa kepuasan setelah menggunakannya. Pengguna akan menilai suatu sumber informasi yang berbasis digital dari pengalaman setelah menggunakan sumber informasi tersebut. Selain itu pengguna juga 
dapat memberikan sebuah respon berupa tingkat kesenangan dalam memenuhi kebutuhan akan sebuah informasi yang diinginkan.

Perlu diketahui bahwa tidak semua informasi yang didapatkan merupakan informasi yang berkualitas. Oleh karenanya suatu informasi dapat dikatakan memiliki kualitas jika informasi tersebut memiliki nilai guna yang dapat menambah wawasan bagi pengguna informasi. Selain itu informasi juga memiliki kualitas jika sesuai dengan kebutuhan yang diinginkan oleh pencari informasi. Hal ini tentu berkaitan dengan rasa kepuasan yang dialami oleh para pengguna suatu sumber informasi seperti repositori. Tingkat kepuasan yang baik ini didapatkan apabila informasi yang mereka terima memiliki nilai guna dan sesuai dengan kebutuhan yang diinginkan. Oleh karena itu, sebuah repositori harus mampu memiliki sistem yang memberikan informasi berkualitas. Selain itu kualitas informasi juga dapat dijadikan sebuah indikator dari kualitas sebuah sistem informasi. Maka dapat dikatakan bahwa kualitas informasi merupakan sebuah pengukuran yang memiliki fokus terhadap pengeluaran informasi yang diproduksi oleh sebuah sistem dan memiliki nilai bagi pengguna (Fendini, 2013). Semakin baik kualitas informasi yang ada maka keputusan yang diambil juga akan lebih tepat. Tentu hal ini akan berbeda apabila informasi yang diterima tidak berkualitas atau memiliki kualitas yang buruk, tentu akan berpengaruh pada tingkat kepuasan yang dirasakan oleh para pengguna repositori tersebut.

Oleh karena itu, RIN harus memiliki kualitas sistem dan kualitas informasi yang baik. Kualitas sistem dan kualitas informasi yang diberikan ini akan memenuhi harapan dan kebutuhan dari para penggunanya, sehingga sikap kepuasan atas penggunaan sebuah repositori dapat tercapai. Maka dari itu sikap merasa puas hanya dapat timbul setelah para pengguna RIN merasakan manfaat dari penggunaan RIN. Hal ini yang menjadi dasar bagi penelitian ini, mengingat Repositori Ilmiah Nasional merupakan wadah atau sarana yang dibuat oleh LIPI, sehingga sudah seharusnya LIPI memiliki kualitas informasi yang baik.
Selain itu RIN juga merupakan sebuah media atau sarana dalam menyimpan dan juga sebagai sumber informasi. Oleh karenanya apabila RIN mampu untuk memenuhi kebutuhan informasi para penggunanya, maka akan berpengaruh terhadap tingkat kepuasan pengguna. Oleh karena itu perlunya penelitian ini dilakukan untuk menganalisa kualitas informasi yang diberikan oleh sistem informasi dari RIN repositori yang dimanfaatkan oleh para penggunanya di lingkup LIPI Bandung, sehingga dapat memberikan tingkat kepuasan yang baik. Penelitian ini bertujuan untuk mengetahui hubungan antara kualitas informasi RIN dengan tingkat kepuasan penggunanya di LIPI Bandung.

\section{B. TINJAUAN PUSTAKA}

Kebutuhan akan informasi dapat dikatakan semakin pesat dan menjadi sesuatu yang harus terpenuhi. Hal ini dikarenakan sudah semakin banyak sumber informasi serta berkembangnya teknologi informasi. Selain itu, pengumpulan dan pengolahan informasi dilakukan oleh berbagai sumber informasi sehingga para pencari informasi bisa langsung memanfaatkannya. Perlu diketahui bahwa perkembangan teknologi juga memberikan dampak pada perkembangan sumber informasi. Sumber informasi dalam bentuk tercetak juga sudah diubah menjadi sumber informasi berbasis digital yang dapat diakses dimana saja dan kapan saja. Hal ini didukung dengan adanya internet yang membuat orang-orang hanya perlu terhubung dengan koneksi internet untuk dapat mengakses dan memanfaatkan sumber informasi yang tersedia.

Namun sumber informasi yang ada di internet masih memiliki kekurangan. Banyaknya pilihan yang tersedia di internet membuat sumber informasi masih diragukan kebenarannya. Salah satu tempat penyedia sumber informasi yang dapat dipercaya di internet adalah hadirnya sumber informasi dari berbagai lembaga yang bergerak di bidang pendidikan atau pengetahuan yang sudah memanfaatkan teknologi informasi. Sumber informasi yang terdapat pada situs tersebut memiliki nilai dan dapat dipercaya karena 
berisikan hasil penelitian terdahulu dan hasil penelitian dari masyarakat akademik yang bersangkutan. Bentuk dari erkembangan sumber informasi ini salah satunya adalah repositori yang dapat diakses melalui internet dan tentu repositori berbasis digital.

Repository atau repositori secara etimologi dapat diartikan sebagai media atau tempat untuk menyimpan. Repository merupakan satu set layanan yang ditawarkan oleh lembaga kepada anggota masyarakat untuk pengelolaan dan penyebaran karya ilmiah dalam bentuk digital yang dibuat oleh lembaga dan anggota masyarakat (Armstrong, 2014). Hal ini merupakan bentuk dari komitmen organisasi atau pihak-pihak tertentu yang menaruh perhatian pada bahan-bahan dalam bentuk digital. Termasuk pelestarian dalam jangka panjang serta organisasi dan akses atau distribusi yang tepat. Sebuah repository dalam bentuk digital memiliki mekanisme untuk mengelola dan menyimpan konten digital. Repositori digital juga tentu memiliki sumber yang dapat dipercaya, dalam bentuknya dapat berupa repository subjek.

Dalam perkembangan saat ini, pengembangan repository telah banyak menyita perhatian dari berbagai kalangan ilmiah di seluruh dunia. Pengembangan repository institutional ini telah menjadi concern bagi kalangan akademisi, peneliti, perguruan tinggi dan lembaga-lembaga riset. Ada berbagai bentuk dan jenis dari repository saat ini, dalam perkembangannya disesuaikan dengan kebutuhan masing-masing. Ada beberapa pengkategorian atau jenis dari repository berdasarkan lingkup dari pengelolaanya dan cakupan atau jenis dari konten yang dikelola. Jenis dari repository ini dibagi menjadi empat macam, yaitu subject-based repository, research repository, national repository, dan repository institutional.

Salah satu contoh repositori yang dibahas dalam penelitian ini adalah RIN atau Repositori Ilmiah Nasional yang diciptakan oleh LIPI. Repositori Ilmiah Nasional ini juga selain memiliki peran sebagai sebuah tempat penyimpanan data, tetapi juga sebagai salah satu sumber informasi digital. Repositori Ilmiah
Nasional memiliki sistem yang sistematis guna memudahkan para penggunannya dalam mendapatkan informasi yang dibutuhkan. Sebagai salah satu sumber informasi yang dimanfaatkan oleh para penggunanya, tentu sudah seharusnya RIN memiliki kualitas informasi. Hal ini karena tidak semua informasi dapat dikatakan berkualitas, informasi merupakan data atau rekaman dari sebuah kejadian yang sudah diolah menjadi pengetahuan yang berguna dalam pengambilan keputusan. Oleh karenanya suatu informasi dikatakan memiliki kualitas dan nilai guna apabila dapat menambah wawasan bagi pengguna informasi.

Suatu informasi harus memiliki kualitas dan nilai guna yang dapat menambah wawasan bagi pengguna informasi. Akan tetapi kualitas informasi juga dapat dijadikan sebuah indikator dari kualitas sebuah sistem informasi. Keberhasilan dari sebuah sistem informasi dapat diukur melalui tiga komponen, yaitu kualitas informasi yang dihasilkan, manfaat dari sistem dan kepuasan pengguna (Buana \& Wirawati, 2018). Berdasarkan penjelasan tersebut, maka dapat dikatakan bahwa kualitas informasi merupakan sebuah pengukuran yang memiliki fokus terhadap pengeluaran informasi yang diproduksi oleh sebuah sistem dan memiliki nilai bagi pengguna. Semakin baik kualitas informasi yang ada maka keputusan yang diambil juga akan lebih tepat. Oleh karenanya, apabila informasi yang diterima tidak berkualitas atau memiliki kualitas yang buruk, akan berpengaruh pada kepuasan yang dirasakan oleh pengguna. Kepuasan yang dirasa oleh pengguna ini juga dapat digunakan sebagai penilaian terhadap kinerja suatu sistem. Teori model dari Doll dan Torkzadeh (1991) yaitu End User Computing Satisfaction (EUCS) merupakan sebuah model teori untuk mengukur bagaimana tingkat kepuasan dari pengguna (Doll \& Torkzadeh, 1991). Model teori ini menjelaskan bagaimana mengukur suatu tingkatan kepuasan dari pengguna terhadap suatu sistem aplikasi, dengan cara membandingkan antara harapan dan kenyataan dari sebuah sistem informasi. 
Sebuah kualitas informasi dapat dilihat dari beberapa indikator. Indikator ini terdiri dari beberapa dimensi yaitu dimensi waktu informasi (time dimension), dimensi konten informasi (content dimension) dan dimensi bentuk informasi (format dimension) (O'brien, 2015). Indikator tersebut tentu memiliki maknanya tersendiri, yaitu 1) Time Dimension, sebuah informasi dapat dikatakan berkualitas jika memenuhi syarat yaitu: a. Currency (Up to date) informasi disampaikan tepat waktu dan cepat sehingga dapat memuaskan pengguna, $b$. Timeliness atau tersedia kapan saja disaat pengguna membutuhkan informasi, dan c. Frequncy atau informasi tersedia dalam periode waktu tertentu atau masuk kategori up to date. 2) Content Dimension, merupakan dimensi dari konten informasi sehingga sebuah informasi dapat dikatakan berkualitas, ada beberapa indikator dalam dimensi ini yaitu: a. Accuracy atau akurat merupakan contoh dari sebuah informasi yang ada haruslah memiliki keakuratan dan bebas dari kesalahan, b. Relevance atau relevan merupakan ciri dari informasi yang berkualitas sehingga informasi yang ada harus sesuai dengan kebutuhan dan keinginan dari pengguna, c. Conciseness atau sebuah informasi yang diberikan haruslah sesuai dengan apa yang dibutuhkan oleh para penggunannya serta memiliki isi yang sesuai. 3) Format Dimension, merupakan bentuk dari informasi yang tersedia. Dimensi format dimaksudkan bagaimana sebuah informasi tersebut dapat sampai pada para penggunannya. Hal ini berkaitan dengan media yang digunakan oleh para pengguna dalam mengakses, apakah online atau tidak, melalui komputer, radio, ponsel atau lainnya.

\section{METODE PENELITIAN}

Penelitian ini menggunakan metode penelitian kuantitatif dengan pendekatan studi korelasional. Hal ini dilakukan karena penelitian ini mengkaji hubungan antara 2 variabel yaitu Kualitas informasi Repositori Ilmiah Nasioanal sebagai variabel independen (X) dan tingkat kepuasan pengguna di LIPI Bandung sebagai variabel dependen (Y). Populasi yang digunakan dalam penelitian ini adalah para peneliti LIPI di kawasan Bandung sebagai para pengguna RIN. Data dianalisis dengan menggunakan analisis statistika deskriptif dan juga analisis statistika inferensial. Pengambilan data digunakan dalam beberapa teknik atau cara, yaitu: 1) angket online, 2) observasi, dan juga 3) studi kepustakaan.

Penelitian ini menggunakan dua jenis data, yaitu 1) Data primer yang berasal dari pengguna yang menjadi sampel penelitian untuk mengisi pertanyaan pada kuesioner yang telah dirancang, 2) Data sekunder yang berasal dari buku, jurnal, dan artikel baik berupa cetak ataupun elektronik yang berhubungan dengan masalah penelitian. Teknik analisis data yang digunakan yaitu teknik analisis statiska deskriptif dan analisis statistika induktif atau inferensial. Analisis statistika deskriptif dalam penelitian ini digunakan untuk menjelaskan hasil jawaban dari kuesioner yang telah disebarkan kepada responden. Analisis ini memiliki tingkat kecenderungan jawaban dari sampel terhadap setiap variabel penelitian, sehingga dapat terlihat melalui jawaban dari setiap item pertanyaan dan pernyataan. Analisis induktif atau inferensial ini bertujuan untuk mengetahui hubungan antara kualitas informasi dari Repositori Ilmiah Nasional sebagai variabel (X) yang mencakup unsur dimensi waktu informasi (time dimension), dimensi konten informasi (content dimension) dan dimensi bentuk bentuk informasi (format dimension) dengan tingkat kepuasan pengguna di LIPI Bandung sebagai variabel (Y). Analisis inferensial dalam penelitian ini menggunakan korelasi Rank Spearman dalam mencari hubungan. Analisis statistik inferensial ini akan menunjukkan tinggi rendahnya sebuah hubungan antar variabel.

\section{HASIL DAN PEMBAHASAN}

Dalam penelitian ini, objek penelitian repositori digital yaitu Repositori Ilmiah Nasional. Repositori Ilmiah Nasional (RIN) adalah sebuah sarana untuk menyimpan, melestarikan dan menjamin ketersediaan akses terhadap penelitian. RIN juga merupakan salah satu repositori yang dikelola oleh satuan kerja PDDI LIPI sehingga memiliki manfaat yang 
baik bagi para penggunanya. Sebagai sebuah media atau sarana dalam menyimpan data hasil dari penelitian, tentu Repositori Ilmiah Nasional ini digunakan oleh peneliti yang diyakini bahwa data akan tersimpan dan dapat dimanfaatkan dengan baik. Penelitian ini juga dilakukan untuk mengetahui adakah hubungan antara kualitas informasi RIN dengan kepuasan para penggunanya. Berdasarkan pengambilan data yang telah dilakukan, digunakan responden penelitian sebanyak 72 orang yang merupakan para peneliti pengguna RIN di LIPI Kota Bandung. Jumlah responden tersebut terdiri dari jenis kelamin laki-laki jumlah 41 orang atau sebesar $57 \%$ dan juga perempuan yang mengisi berjumlah 31 orang atau sebesar $43 \%$. Seluruh responden tersebut merupakan para peneliti yang ada di LIPI Bandung.

Selain itu, 72 responden tersebut terbagi menjadi beberapa satuan kerja yang ada di LIPI Bandung. Satuan kerja yang di LIPI Bandung ini meliputi Pusat Penelitian Informatika, Balai Pengembangan Instrumensi, Pusat Penelitian Elektronika dan Telekomunkasi, Pusat Penelitian Geoteknologi, Loka Penelitian Teknologi Bersih dan juga Pusat Penelitian Tenaga Listrik dan Mekatronika. Meskipun ada beberapa satuan kerja yang terdapat di LIPI Bandung, akan tetapi satuan kerja Pusat Penelitian Informatika merupakan satuan kerja yang paling banyak menggunakan Repositori Ilmiah Nasional dengan 22 responden atau sebesar $31 \%$. Para peneliti ini mengetahui adanya RIN ini dari berbagai sumber yang ada, seperti bimbingan teknis RIN yang dilaksanakan oleh PDDI LIPI Bandung sebagai pengelola RIN. Data tersebut menunjukkan bahwa sosialisasi yang dilakukan melalui bimbingan teknis mampu dimaksimalkan dengan baik. Selain sebagai media untuk memberitahukan kepada para peneliti tentang adanya RIN, bimbingan teknis juga digunakan sebagai media dalam menyebarkan kepada peneliti yang lain tentang RIN. Setelah data dikumpulkan dari angket yang disebar secara online, hasil yang telah didapatkan kemudian dianalisa menggunakan analisis tabulasi silang. Hasil analisis tabulasi silang akan menunjukkan hubungan antara kualitas informasi dari
Repositori Ilmiah Nasional dengan tingkat kepuasan pengguna di LIPI Bandung.

\section{Kualitas Informasi Repositori Ilmiah Nasional}

Kualitas yang diberikan oleh sebuah sistem informasi dari sumber informasi digital memiliki nilai tersendiri. Kualitas informasi yang diberikan dapat menjadi sebuah indikator bahwa sumber informasi tersebut memiliki kualitas sebagai sumber informasi yang dipercaya. Ketersediaan informasi yang berkualitas serta kemudahan dalam penggunaan dari sebuah sistem, merupakan faktor yang penting bagaimana sebuah sumber informasi digital dapat digunakan dengan sebaik mungkin (Nuryanti, 2021). Dalam penelitian ini, RIN merupakan sistem informasi yang mampu memberikan kualitas dalam informasi yang diberikan kepada para penggunanya. Kualitas informasi yang diberikan oleh RIN diukur berdasarkan beberapa indikator, yaitu time dimension, content dimension dan format dimension. Data tersebut dapat menjadi gambaran bagaimana kualitas informasi merupakan hal yang penting bagi sebuah sumber informasi seperti Repositori Ilmiah Nasional.

Berdasarkan hasil analisis pada tabel 1, menunjukkan bahwa responden menilai kualitas informasi yang diberikan RIN, masuk pada kategori cukup yaitu sebesar 56,9\% atau 41 respoden dari 72 responden yang digunakan sebagai data responden. Data yang ada pada tabel 1 juga berdasarkan pada informasi yang diberikan oleh RIN memiliki kualitas yang cukup baik. Berdasarkan indikator dari kualitas informasi yang pertama yaitu time dimension dari Repositori Ilmiah Nasional memiliki kualitas informasi dengan kategori baik. Hal ini dapat dilihat pada tabel 4 dengan nilai sebesar $84,7 \%$. RIN juga mampu untuk memberikan informasi yang termasuk ke dalam indikator time dimension. Indikator time dimension ini mampu dipenuhi karena RIN memberikan informasi yang masuk ke dalam indikator time dimension. Indikator tersebut diantaranya adalah currency (up to date), yaitu informasi disampaikan tepat waktu dan cepat sehingga 
dapat memuaskan pengguna, timeliness atau tersedia kapan saja disaat pengguna membutuhkan informasi, dan frequncy atau informasi tersedia dalam periode waktu tertentu atau masuk kategori up to date.

Indikator dari kualitas informasi kedua adalah content dimension yang menunjukkan pada kategori baik. Data yang didapatkan pada tabel 5 menunjukkan bahwa responden menilai kualitas informasi berdasarkan content dimension dari Repositori Ilmiah Nasional masuk pada kategori baik dengan nilai sebesar $72,2 \%$. Hal ini disebabkan karena RIN mampu memberikan informasi yang masuk ke dalam indikator content dimension, yaitu accuracy atau jelas, sebuah informasi yang ada haruslah akurat dan bebas dari kesalahan, relevance atau informasi yang ada harus sesuai dengan kebutuhan dari pengguna butuhkan atau inginkan, dan conciseness atau informasi yang diberikan haruslah sesuai dengan apa yang dibutuhkan oleh para penggunannya. Indikator tersebut merupakan bagian dari content dimension yang merupakan indikator sebuah informasi yang memiliki kualitas.

Selanjutnya pada indikator kualitas informasi yang ketiga yaitu berdasarkan format dimension dari Repositori Ilmiah Nasional juga memberikan hasil yang baik. Hal tersebut dapat dilihat pada tabel 6 yang menunjukkan nilai sebesar $86,1 \%$. Hal ini didapatkan setelah RIN mampu untuk memberikan informasi yang disajikan dalam bentuk atau format yang mudah dimengerti dan juga dapat diakses dengan mudah, hal tersebut termasuk kedalam indikator format dimension. Dimensi format dimaksudkan bagaimana sebuah informasi tersebut dapat sampai pada para penggunanya. Hal ini berkaitan dengan media yang digunakan oleh para pengguna dalam mengakses, apakah online atau tidak, melalui komputer, radio, ponsel atau lainnya, sehingga pengguna dari RIN menilai bahwa bentuk informasi yang diberikan sudah baik.

\section{Kepuasan Penggunaan Repositori Ilmiah Nasional}

Berdasarkan pada tabel 2, menunjukkan bahwa kepuasan dari penggunaan RIN yaitu berada pada kategori tinggi yang bernilai $86,1 \%$. Hal ini juga menunjukkan bahwa pengguna merasa puas dengan informasi yang ada pada RIN. Kemampuan dari sistem informasi yang dimiliki oleh RIN sebagai sebuah repositori mampu memenuhi kebutuhan informasi, sehingga respon yang diberikan adalah tingginya tingkat kepuasan dari pengguna. Kualitas informasi dari RIN masuk pada kategori cukup, pada tabel 1 menunjukkan nilai sebesar 56,9\%. Penilaian tersebut memberikan dampak pada kepuasan dengan kategori tinggi akan penggunaan dari RIN yaitu sebesar $86,1 \%$. Data tersebut menunjukkan bagaiamana peran dari kualitas informasi memiliki pengaruh terhadap tingkat kepuasan dalam penggunaan RIN. Oleh karenanya, semakin baik kualitas informasi yang diberikan oleh RIN, maka semakin baik tingkat kepuasan yang dirasakan. Akan tetapi jika kualitas informasi yang diberikan menurun, maka tingkat kepuasan yang didapatkan dalam penggunaan RIN juga akan menurun. Respon yang berupa kepuasan yang dirasakan oleh pengguna ini, merupakan sebuah evaluasi subjektif bagaimana sebuah sistem sumber informasi seperti RIN ini mampu memberikan kualitas dalam setiap informasi yang diberikan. Selain itu kepuasan dari para pengguna juga dapat digunakan sebagai suatu manfaat yang dapat dirasakan langsung oleh para pengelola dari sistem informasi tersebut (Bahari, 2010).

\section{Hubungan Kualitas Informasi dengan Tingkat Kepuasan}

Berdasarkan data yang telah diolah diketahui bahwa kualitas informasi dari Repositori Ilmiah Nasional memiliki keterkaitan dengan tingkat kepuasan pengguna di LIPI Bandung. Selain itu kualitas informasi dari RIN, masuk kedalam kategori cukup karena mampu memenuhi tiga indikator. Dimensi kualitas sebuah infomasi dilihat dari beberapa dimensi yaitu dimensi waktu informasi (time dimension), dimensi konten informasi (content dimension) dan dimensi bentuk informasi (format dimension). Hal ini juga semakin dikuatkan dengan data hasil analisis korelasi antara kualitas informasi dari Repositori Ilmiah 
Nasional dengan tingkat kepuasan pengguna di LIPI Bandung. Hasil dari analisis korelasi menunjukkan bahwa kualitas dari Repositori Ilmiah Nasional dengan tingkat kepuasan penggunaan Repositori Ilmiah Nasional memiliki hubungan yang signifikan. Hubungan ini didapatkan dengan nilai signifikansi lebih kecil dari nilai $\alpha(0,000 \leq 0.05)$, sehingga menunjukkan bahwa adanya hubungan yang signifikan antara kualitas informasi RIN dengan kepuasan pengguna di LIPI Bandung. Selain itu tabel 3 menunjukkan koefisien korelasi sebesar 0,829. Hal tersebut menunjukkan bahwa keeratan korelasi antara variabel tersebut masuk kedalam kategori sangat kuat. Dapat dilihat juga nilai koefisien korelasi bersifat positif, artinya hubungan antara kedua variabel juga bernilai positif. Semakin tinggi kualitas Informasi yang diberikan oleh Repositori Ilmiah Nasional maka akan semakin tinggi juga tingkat kepuasan penggunaan dari Repositori Illmiah Nasional.

Berdasarkan hasil dari data yang telah didapatkan, menunjukkan bahwa kualitas informasi yang diberikan oleh sistem dari Repositori Ilmiah Nasional dapat memberikan sebuah pengukuran bagaimana kinerja dari sebuah sistem yang diberikan oleh Repositori Ilmiah Nasional sebagai sebuah repositori. Respon yang diberikan adalah tingkatan kepuasan dari penggunaan Repositori Ilmiah Nasional itu sendiri. Hal ini didukung dengan data pada tabel 1 dengan kualitas informasi yang diberikan RIN yaitu sebesar 56,9\%, sehingga penilaian tersebut dapat memberikan para penggunanya rasa kepuasan dengan kategori yang tinggi akan penggunaan dari RIN yaitu sebesar $86,1 \%$. Berdasarkan penjelasan tersebut, maka dapat dikatakan bahwa kualitas informasi merupakan sebuah pengukuran yang memiliki fokus terhadap pengeluaran informasi yang diproduksi oleh sebuah sistem dan memiliki nilai bagi pengguna. Nilai guna tersebut nantinya akan memberikan rasa kepuasan dari pengguna sistem yaitu RIN. Tingkatan rasa kepuasan tersebut dapat dirasakan setelah pengguna menggunakan RIN. Berdasarkan penjelasan tersebut, dapat disimpulkan bahwa kepuasan dari pengguna terkait dengan respon atau sikap terhadap interaksi dari suatu sistem sehingga dapat dimanfaatkan secara maksimal (Fendini, 2013).

Data tersebut juga menunjukkan bahwa sebuah kualitas informasi mampu untuk memberikan pengaruh terhadap tingkat kepuasan dari penggunaan suatu sistem informasi, khususnya dalam sebuah sumber informasi seperti repositori. Hal ini semakin meyakinkan data dari penelitian sebelumnya. Seperti penelitian yang dilakukan oleh Suharno Pawirosumarto pada tahun 2016, penelitian ini menganalisis sebuah kualitas layanan terhadap kepuasan pengguna sistem e-learning (Pawirosumarto, 2016). Selain itu di era serba digital saat ini, tidak dapat dipungkiri bahwa informasi yang menyebar dengan cepat melalui internet sulit dikendalikan kebenarannya dan kualitasnya. Oleh karenanya, para pencari informasi kesulitan dalam mendapatkan informasi yang berkualitas dari sebuah sumber informasi. Data ini juga dapat menjadi pertimbangan betapa pentingnya sebuah informasi bagi para pencari informasi. Informasi ternyata memiliki nilai dan kebutuhan informasinya tersendiri.

Setiap individu yang merasa terpuaskan karena kebutuhan informasinya terpenuhi, akan memberikan penilaian bagaimana suatu sumber informasi mampu bekerja dengan baik. Kepuasan dapat diartikan sebagai suatu keadaan seseorang atau kelompok yang telah berhasil memenuhi kebutuhan dan keinginannya sesuai yang diharapkan. Kepuasan adalah perihal rasa akan puas dan senang terhadap sesuatu yang diinginkan oleh dirinya meskipun harus melalui kesulitan lebih dahulu (Kamus Besar Bahasa Indonesia, 2016). Kepuasan juga dapat diartikan sebagai perasaan seseorang yang merasa senang dan lega karena telah mengkonsumsi ataupun menggunakan suatu produk atau jasa dengan mendapatkan layanan dengan baik. End User Computing Satisfaction (EUCS) merupakan teori yang digunakan dalam penelitian ini untuk mengukur tingkat kepuasan dari pengguna terhadap suatu sistem aplikasi yaitu RIN dengan membandingkan antara harapan dan kenyataan dari sebuah sistem informasi. Teori ini menjelaskan bagaimana kepuasan dari pengguna dapat diketahui dengan menilai 
perasaan yang dirasakan setelah menggunakan suatu sistem.

Oleh karenanya menjadi hal yang perlu diperhatikan bagaimana sebuah informasi disebut berkualitas, karena hanya informasi yang baik, bermanfaat, terbaru dan akurat yang dapat dikatakan sebagai sebuah informasi yang berkualitas (Azemi, 2017). Dalam hal ini, RIN sebagai media sumber informasi yang digunakan oleh para peneliti mampu memberikan informasi yang dianggap berkualitas. Kualitas informasi dan kualitas layanan dari sebuah sistem merupakan faktor penentu kepuasan dari penggunaan sebuah sistem sumber informasi (Sharma \& Lijuan, 2015). Kualitas informasi dari RIN juga dapat digunakan sebagai sebuah media untuk mengukur bagaimana interaksi antara pengguna dengan sistem itu sendiri. Oleh karenanya, hubungan antara kualitas informasi dengan rasa kepuasan dari pengunaan sumber informasi memiliki hubungan satu sama lain. Respon ini dapat terjadi karena konsep dari informasi yang berkualitas, pada akhirnya akan menghasilkan tindakan yang dapat digambarkan dengan rasa kepuasan. Hubungan yang dimaksud adalah ketika variabel antara data atau informasi yang diberikan oleh sebuah sumber informasi, dapat diubah menjadi pengetahuan yang bermanfaat dari pengguna sekaligus pencari informasi tersebut. Oleh karena itu, apabila pencari informasi telah mendapatkan pengetahuan yang diinginkan, maka akan menghasilkan sebuah tindakan atas pengetahuan tersebut. Pada akhirnya akan memberikan hasil berupa tingkat atau rasa kepuasan karena terpenuhinya kebutuhan akan informasi.

\section{E. KESIMPULAN}

Berdasarkan data yang telah didapatkan, diketahui bahwa kualitas informasi dari Repositori Ilmiah Nasional memiliki hubungan dengan tingkat kepuasan penggunaan terhadap Repositori Ilmiah Nasional di LIPI Kawasan Bandung. Selain itu data yang didapatkan juga menunjukkan bahwa responden menilai kualitas informasi dari Repositori Ilmiah Nasional memiliki kualitas yang cukup untuk dikatakan berkualitas sehingga menimbulkan rasa puas dalam penggunaan Repositori Ilmiah Nasional. Kualitas informasi yang baik tersebut pada akhirnya memberikan rasa akan kepuasan yang tinggi. Selain itu keeratan korelasi antara kualitas informasi dari Repositori Ilmiah Nasional memiliki hubungan dengan tingkat kepuasan penggunaan terhadap Repositori Ilmiah Nasional masuk kedalam kategori sangat kuat antara variabel kualitas informasi dan tingkat kepuasan penggunaan. Kualitas informasi berdasarkan time dimension, content dimension, dan format dimension memiliki hubungan yang sangat kuat terhadap tingkat kepuasan dari penggunanya.

Selain itu, Repositori Ilmiah Nasional (RIN) sebagai sebuah repositori mampu dalam memaksimalkan fungsinya demi memenuhi kebutuhan dari para penggunanya. Repositori Ilmiah Nasional dapat meningkatkan kinerja sistem dalam mengolah informasi yang dimilikinya sehingga dapat memberikan informasi dengan bentuk atau format yang lebih mudah dimengerti. Hal ini dikarenakan format dari informasi yang diberikan sudah baik akan tetapi jika diberikan dalam format yang lebih mudah akan semakin mempermudah kinerja dari pengguna. Repositori Ilmiah Nasional juga diharapkan dapat membuka akses informasi lebih mudah dan cepat. Pengguna Repositori Ilmiah Nasional merasa akses yang ada masih kurang memudahkan. Hal ini dapat dipahami karena RIN memiliki kualitas sistem dalam menjaga kerahasiaan data dengan baik. Repositori Ilmiah Nasional ini juga diharapkan dapat digunakan oleh masyarakat umum secara luas, karena untuk saat ini Repositori Ilmiah Nasional hanya dapat digunakan secara bebas oleh pihak-pihak tertentu saja seperti peneliti, pemberi dana dan juga lembaga yang berafiliasi dengan LIPI. Memiliki manfaat yang baik tentu membuat RIN juga dapat menjadi sebuah media yang dapat dirasakan untuk masyarakat secara luas, karena untuk saat ini masyarakat umum masih memiliki batasan dalam mengakses RIN. 


\section{DAFTAR PUSTAKA}

Armstrong, M. (2014). Institutional repository management models that support faculty research dissemination. OCLC Systems and Services, 30(1), 43-51. https://doi.org/ 10.1108/OCLC-07-2013-0028

Azemi, N. A., Zaidi, H., \& Hussin, N. (2018). Information quality in organization for better decision-making. International Journal of Academic Research in Business and Social Sciences, 7(12), 429-437 https://doi.org/10.6007/ijarbss/v7i1 $2 / 3624$

Bahari, A. (2010). Impact of system quality, information quality and service quality on performance. Universiti Malaysia Sabah, 3(2), 1-6.

Buana, I. B. G. M., \& Wirawati, N. G. P. (2018). Pengaruh kualitas sistem informasi, kualitas informasi, dan perceived usefulness pada kepuasan pengguna sistem informasi akuntansi. E-Jurnal Akuntansi Universitas Udayana, 22(1), 683-713.

Doll, W. J., \& Torkzadeh, G. (1991). The measurement of end-user computing satisfaction : theoretical considerations. MIS Quarterly, 15(1), 5-10. https://doi.org/10.2307/249429

Fendini, D. S. (2013). Pengaruh kualitas sistem dan kualitas informasi terhadap kepuasan pengguna (survei pada karyawan pengguna aplikasi pelayanan pelanggan terpusat (ap2t) di PT. PLN (Persero) area Malang). Jurnal Administrasi Bisnis, 4(1), 1-11.
Kamus Besar Bahasa Indonesia. (2016). Kepuasan. Balai Pustaka. https://kbbi.kemdikbud.go.id/

Nuryanti, Y. (2021). Understanding the links between system quality, information quality, service quality, and user satisfaction in the context of online learning. International Journal of Social and Management Studies, 02(04), 54-64. https://doi.org/10.5555/ijosmas.v2i4.51

O'brien, J. A., Ogiela, L., \& Ogiela, M. R. (2015). Management information systems. Lecture Notes in Electrical Engineering, 331(2), 449-456. https://doi.org/10.1007/ 978-94-017-9618-7 44

Pawirosumarto, S. (2016). Pengaruh kualitas sistem, kualitas informasi, dan kualitas layanan terhadap kepuasan pengguna sistem e-learning. Ilmiah Manajemen, $33(6), \quad 2119-2123$. https://doi.org/10.1021/ma9919110

Suwanto, S. A. (2017). Manajemen layanan repository perguruan tinggi. Lentera Pustaka: Jurnal Kajian Ilmu Perpustakaan, Informasi dan Kearsipan, 3(2), 165-176. https://doi.org/10.14710/lenpust.v3i2.1674 0

Sharma, G., \& Lijuan, W. (2015). The effects of online service quality of e-commerce websites on user satisfaction. Electronic Library, 33(3), 468-485. https://doi.org/ 10.1108/EL-10-2013-0193 


\section{DAFTAR TABEL}

Tabel 1. Kategori kualitas informasi RIN di LIPI Bandung

\begin{tabular}{ccc}
\hline Kualitas Informasi dari Repositori Ilmiah Nasional & $\begin{array}{c}\text { Frekuensi } \\
(\mathbf{n = 7 2})\end{array}$ & $\%$ \\
\hline Baik & 29 & $40,3 \%$ \\
Cukup & 41 & $56,9 \%$ \\
Kurang & 2 & $2,8 \%$ \\
\hline
\end{tabular}

Sumber: Data primer diolah, tahun 2020

Tabel 2. Kategori tingkat kepuasan penggunaan RIN di LIPI Bandung

\begin{tabular}{ccc}
\hline $\begin{array}{c}\text { Kepuasan dalam penggunaan Repositori Ilmiah } \\
\text { Nasional }\end{array}$ & $\begin{array}{c}\text { Frekuensi } \\
(\mathbf{n = 7 2})\end{array}$ & $\%$ \\
\hline Tinggi & 62 & $86,1 \%$ \\
Sedang & 9 & $12,5 \%$ \\
Rendah & 1 & $1,4 \%$ \\
\hline
\end{tabular}

Sumber: Data primer diolah, tahun 2020

Tabel 3. Hubungan kualitas informasi dari RIN dengan tingkat kepuasan pengguna di LIPI Bandung

\begin{tabular}{ccccc}
\hline Variabel & $\begin{array}{c}\text { Koefisein } \\
\text { Korelasi }\end{array}$ & $\begin{array}{c}\text { Tingkat } \\
\text { Signifikan }\end{array}$ & Keputusan & Kesimpulan \\
\hline $\begin{array}{c}\text { Kualitas Informasi } \\
(\mathrm{X})-\text { Kepuasan (Y) }\end{array}$ & 0,829 & 0,000 & $\mathrm{H}_{0}$ ditolak & Terdapat hubungan \\
\hline
\end{tabular}

Sumber: Data primer diolah, tahun 2020

Tabel 4. Kualitas informasi berdasarkan time dimension di Repositori Ilmiah Nasional

\begin{tabular}{ccc}
\hline Kategori & $\begin{array}{c}\text { Frekuensi } \\
(\mathbf{n = 7 2})\end{array}$ & \% \\
\hline Baik & 61 & 84,7 \\
Cukup & 10 & 13,9 \\
Kurang & 1 & 1,4 \\
\hline
\end{tabular}

Sumber: Data primer diolah, tahun 2020 


\section{DAFTAR TABEL}

Tabel 5. Kualitas informasi berdasarkan content dimension di Repositori Ilmiah Nasional

\begin{tabular}{ccc}
\hline Kategori & $\begin{array}{c}\text { Frekuensi } \\
(\mathbf{n = 7 2})\end{array}$ & \% \\
\hline Baik & 52 & 72,2 \\
Cukup & 18 & 25 \\
Kurang & 2 & 2,8 \\
\hline
\end{tabular}

Sumber: Data primer diolah, tahun 2020

Tabel 6. Kualitas informasi berdasarkan format dimension di Repositori Ilmiah Nasional

\begin{tabular}{ccc}
\hline Kategori & $\begin{array}{c}\text { Frekuensi } \\
(\mathbf{n = 7 2})\end{array}$ & $\mathbf{\%}$ \\
\hline Baik & 62 & 86,1 \\
Cukup & 8 & 11,1 \\
Kurang & 2 & 2,8 \\
\hline
\end{tabular}

Sumber: Data primer diolah, tahun 2020 